\title{
ROLA KONGRESU WŁADZ LOKALNYCH I REGIONALNYCH RADY EUROPY W ROZWOJU MIĘDZYNARODOWEJ WSPÓŁPRACY SAMORZĄDOWEJ
}

Kongres Władz Lokalnych i Regionalnych Rady Europy (Congress of Local and Regional Authorities of Europe - CLRAE) jest zgromadzeniem przedstawicieli samorządu terytorialnego reprezentujących państwa Rady Europy. To najstarsza tego typu instytucja o charakterze paneuropejskim, która ma swoje oparcie w traktatach międzynarodowych. ${ }^{38}$ CLRAE skupia przedstawicieli władz lokalnych i regionalnych, reprezentujących łącznie ponad 200 tysięcy samorządów z 47 krajów członkowskich Rady Europy. Fakt ten sprawia, że pomimo swoich dość ograniczonych kompetencji (głównie doradczych), Kongres odgrywa ważną rolę w rozwoju międzynarodowej współpracy samorządowej.

\section{Historia rozwoju CLRAE}

Od początku istnienia Rady Europy jednym z jej priorytetów było promowanie samorządu terytorialnego. Dlatego historia CLRAE zaczyna się już w latach 50-tych $\mathrm{XX}$ wieku. Jednym z pierwszych impulsów do powstania paneuropejskiej instytucji skupiającej reprezentantów samorządu terytorialnego była rezolucja Zgromadzenia Parlamentarnego Rady Europy z 9 czerwca 1955 roku. ${ }^{39}$ Następnie, na podstawie rezolucji Komitetu Ministrów Rady Europy, ${ }^{40} 12$ stycznia 1957 roku w Strasburgu, odbyła się pierwsza sesja Europejskiej Konferencji Władz Lokalnych (obradującej na wzór Zgromadzenia Parlamentarnego Rady Europy). Było to pierwsze tego typu

\footnotetext{
* $\quad$ Autor jest wiceprzewodniczącym polskiej delegacji do Zgromadzenia Parlamentarnego Rady Europy.

38 Drugą instytucją, mającą oparcie w traktatach międzynarodowych, jest Komitet Regionów Unii Europejskiej i choć obie formalnie powołano w 1994 roku, to CLRAE jest historycznie starsza, a jej rozwój rozpoczął się w latach 50-tych XX wieku.

39 Recommendation 76 (1955) adopted by Parliamentary Assembly Council of Europe (09.06.1955) tryb dostępu oficjalna strona internetowa Zgromadzenia Parlamentarnego Rady Europy: http://assembly.coe.int, dnia 11.12.2012 r.

40 Resolution (55) 16 adopted by the Ministers' Deputies (10.10.1955), tryb dostępu: https://wcd.coe.int, dnia 11.12.2012 r.
} 
zgromadzenie w Europie, a od 1961 roku uzyskało status organu pomocniczego Rady Europy. Następnie w 1975 roku Komitet Ministrów Rady Europy rozszerzył skład Konferencji również o przedstawicieli regionów europejskich, powołując Konferencję Władz Lokalnych i Regionalnych Europy, ${ }^{41}$ zaś w 1979 roku przemianowano ją na Stałą Konferencję Władz Lokalnych i Regionalnych Europy. ${ }^{42}$ Kolejnym ważnym krokiem było uchwalenie 15 października 1985 roku Europejskiej Karty Samorządu Lokalnego (European Charter of Local Self-government), która stała się podstawą do dalszego trwałego rozwoju organu skupiającego reprezentantów władz lokalnych i regionalnych. W 1994 roku Komitet Ministrów Rady Europy zdecydował się przekształcić Stałą Konferencję Władz Lokalnych i Regionalnych Europy w Kongres Władz Lokalnych i Regionalnych (CLRAE), nadając mu nowy statut i większe kompetencje. ${ }^{43}$ Od tamtej pory statut CLRAE zmieniany był jeszcze kilkakrotnie (m.in. w 2000, 2007 i 2011 roku $^{44}$ ), dostosowując struktury Kongresu do nowych wyzwań.

\section{Skład i struktura CLRAE}

Kongres Władz Lokalnych i Regionalnych Rady Europy grupuje 636 członków (318 przedstawicieli i 318 zastępców). Liczba mandatów dla każdego państwa jest taka sama jak w Zgromadzeniu Parlamentarnym Rady Europy. Skład delegacji odnawiany jest co 2 lata.

Każde z państw stosuje własne procedury przy wyborze członków CLRAE. Należy jednak spełnić pewne obowiązkowe wymogi. Reprezentanci muszą posiadać mandat pochodzący z wyborów regionalnych lub lokalnych (pośrednich lub bezpośrednich). Skład delegacji powinien proporcjonalnie odzwierciedlać poszczególne części kraju oraz wszystkie szczeble samorządu terytorialnego. Swoich przedstawicieli powinny posiadać główne opcje polityczne reprezentowane we władzach lokalnych i regionalnych. Ponadto w składzie delegacji muszą znaleźć się zarówno kobiety jak i mężczyźni (w 2008 roku wprowadzono wymóg co najmniej 30\% płci słabiej reprezentowanej w składzie delegacji).

Rzeczpospolita Polska posiada w CLRAE 12 miejsc dla przedstawicieli i 12 miejsc dla ich zastępców. Reprezentanci są rekomendowani przez polskie organi-

Resolution (75) 4E, adopted by the Ministers' Deputies (19.02.1975), tryb dostępu: https://wcd.coe.int, dnia 11.12.2012 r.

42 The Congress / RES 104 (1979) E (16.10.1979), tryb dostępu: https://wcd.coe.int, dnia 11.12.2012 r.

43 Statutory Resolution (94) 3, relating to the setting up of the Congress of Local and Regional Authorities of Europe, adopted by the Committee of Ministers (14.01.1994), tryb dostępu: http://conventions.coe.int/Treaty/EN/ Treaties/Html/Resol9403.htm, dnia 11.12.2012 r.

44

Statutory Resolution (2000) 1, adopted by the Committee of Ministers (15.03.2000); Statutory Resolution CM/ Res (2007) 6, adopted by the Committee of Ministers (02.05.2007); Statutory Resolution CM/Res (2011)2, adopted by the Committee of Ministers (19.01.2011), tryb dostępu: https://wcd.coe.int, dnia 11.12.2012 r. 
zacje samorządu terytorialnego - Związek Województw Rzeczpospolitej Polskiej, ${ }^{45}$ Związek Miast Polskich, Związek Gmin Wiejskich RP, Związek Powiatów Polskich, Unię Metropolii Polskich, Unię Miasteczek Polskich. ${ }^{46}$

Poza delegacjami narodowymi państw członkowskich Rady Europy istnieje także status obserwatora, który posiadają inne organizacje europejskie zajmujące się problemami samorządowymi. ${ }^{47}$

Członkowie CLRAE zorganizowani są w grupy polityczne. ${ }^{48}$ Największą frakcją jest European People's Party - Christian Democrats, EPP/CD (214 członków, przewodniczący Artur Torres Pereira z Portugalii). Drugą pod względem wielkości jest Socialist Group, SOC (166 członków, przewodniczący Gudrun Mosler-Tornstrom z Austrii), zaś kolejne to Independent and Liberal Democrat Group, ILDG (86 członków, przewodniczący Knud Andersen z Danii) oraz European Conservatives \& Reformists Group, ECR (30 członków, przewodniczący Halldor Halldorsson z Islandii). Ponadto aż 127 członków Kongresu Władz Lokalnych i Regionalnych Rady Europy jest niezrzeszonych w grupach politycznych. ${ }^{49}$

Wśród polskich przedstawicieli jedenastu należy do EPP/CD (głównie z Platformy Obywatelskiej i Polskiego Stronnictwa Ludowego), dwóch do SOC (jeden przedstawiciel Sojusz Lewicy Demokratycznej i jeden niezależny), dwóch do ECR (jeden reprezentujący Prawo i Sprawiedliwość i jeden niezależny), zaś jeden członek do ILDG (niezależny). Natomiast ośmiu przedstawicieli polskiej delegacji nie jest zrzeszona w żadnych grupach politycznych.

Kongres Władz Lokalnych i Regionalnych Rady Europy podzielony jest na dwie izby - Izbę Władz Lokalnych i Izbę Regionów. Zgodnie ze statutem sesje plenarne zgromadzenia powinny odbywać się co najmniej raz w roku w Strasburgu (zazwyczaj są dwie sesje w roku).

Pracami CLRAE kieruje Przewodniczący wybierany przez obie Izby na dwuletnią kadencję. Reprezentuje on Kongres w relacjach z organami Rady Europy oraz innymi międzynarodowymi organizacjami. ${ }^{50}$

45 Związek Województw Rzeczpospolitej Polskiej reprezentuje najwięcej, bo 6 członków i 6 zastępców. Wszyscy oni zasiadają w Izbie Regionów.

46 Skład polskiej delegacji na dzień 14.12.2012 r.: Komitet Regionów - Lucyna Andrysiak, Wojciech Jankowiak, Marek Mazur, Urszula Pasławska, Elżbieta Polak, Andrzej Pruszkowski, Michał Czarski, Grzegorz Grzelak, Bernardetta Hordejuk, Daria Sapińska, Agnieszka Sobolewska, Tatiana Sokołowska; Komitet Władz Lokalnych: Jolanta Barska, Walery Czarnecki, Judyta Lemm, Leszek Świętalski Piotr Uszok, Dariusz Wróbel, Jan Brons, Tadeusz Ferenc, Tatiana Kędziora, Marek Miros, Elżbieta Smolińska, jeden wakat; zob. http://www.coe.int/t/congress/

47 Pełna lista organizacji które mają status obserwatora przy Kongresie Władz Lokalnych i Regionalnych, znajduje się na stronie: http://www.coe.int/t/congress/whoswho/associations-obs_en.asp?mytabsmenu=4.asp

48 Podobnie jak w przypadku Zgromadzenia Parlamentarnego Rady Europy czy Parlamentu Europejskiego.

49 Tak duża liczba członków niezrzeszonych w grupach politycznych jest charakterystyczna dla Kongresu Władz Lokalnych i Regionalnych. Wynika to głównie z faktu, że duża część samorządowców nie należy do partii politycznych w swoich krajach, a tym samym nie chce przystępować do grup politycznych w Kongresie. Dla porównania w Zgromadzeniu Parlamentarnym Rady Europy liczba niezależnych członków waha się zazwyczaj w okolicach 30 osób.

5016 października 2012 roku na dwuletnią kadencję Przewodniczącego został wybrany Austriak Herwig van Staa (EPP/CD). 
Izba Władz Lokalnych oraz Izba Regionów wybierają swoje prezydia w składzie: przewodniczący ${ }^{51}$ czterech wiceprzewodniczących oraz czterech członków. ${ }^{52}$ Połączone prezydia obu Izb tworzą prezydium CLRAE (na czele z Przewodniczącym Kongresu). Prezydium m.in. koordynuje prace Kongresu, przygotowuje jego budżet oraz misje obserwacyjne na wybory samorządowe, decyduje o podziale miejsc w poszczególnych komisjach, może również przygotowywać raporty i przedkładać je pod obrady Kongresu.

Kolejnym ważnym organem wewnętrznym CLRAE jest Komitet Stały. Zapewnia on działalność Kongresu pomiędzy sesjami plenarnymi. W jego skład wchodzą członkowie prezydium oraz przewodniczący delegacji krajowych. Przewodniczący komisji i szefowie grup politycznych uczestniczą w pracach Komitetu Stałego bez prawa głosu.

W 2010 roku po reformie statutu CLRAE zmieniono również strukturę, metody pracy i zadania komisji stałych Kongresu. Obecnie funkcjonują tylko trzy komisje. Zadaniem Komisji Monitorującej (Monitoring Committee) jest monitorowanie stosowania postanowień Europejskiej Karty Samorządu Lokalnego w krajach członkowskich. Komisja przygotowuje raporty na temat stanu demokracji lokalnej i regionalnej w państwach członkowskich. Do kompetencji Komisji Zarządzania (Governance Committee) należą m.in. kwestie związane ze statutowymi uprawnieniami CLRAE w takich obszarach jak zarządzanie instytucjonalne, współpraca transgraniczna i międzyregionalna, finanse publiczne, e-demokracja. Z kolei celem Komisji do Spraw Bieżących (Current Affairs Committee) jest badanie z punktu widzenia podstawowych wartości Rady Europy roli władz lokalnych i regionalnych w takich dziedzinach jak m.in. edukacja, kultura, zrównoważony rozwój. Komisja analizuje również nowe wyzwania stojące przed samorządem terytorialnym.

W ramach CLRAE funkcjonuje także grupa niezależnych ekspertów w sprawie Europejskiej Karty Samorządu Lokalnego skupiająca fachowców (z dziedziny prawa, finansów, polityki) specjalizujących się w zagadnieniach samorządu terytorialnego. Podstawowym zadaniem grupy jest udzielanie pomocy prawnej organom Kongresu, a zwłaszcza wspomaganie pracy trzech komisji CLRAE. Polskim przedstawicielem w grupie jest profesor Michał Kulesza.

\section{Zadania i kompetencje CLRAE}

W swoim założeniu Kongres Władz Lokalnych i Regionalnych miał być głosem europejskich regionów i gmin w Radzie Europy. To forum, na którym lo-

\footnotetext{
51 Od 16 października 2012 roku na czele Izby Władz Lokalnych stoi Francuz Jean-Claude Frécon (SOC), a Izby Regionów Ukrainka Nataliya Romanova (ILDG).

52 Ponadto na posiedzenia Prezydium mogą być zapraszani z głosem doradczym szefowie grup politycznych, przewodniczący komisji oraz grup roboczych.
} 
kalni i regionalni przedstawiciele mogą omawiać wspólne problemy i dzielić się doświadczeniami. ${ }^{53}$

Głównym zadaniem Kongresu Władz Lokalnych i Regionalnych jest doradzanie Komitetowi Ministrów i Zgromadzeniu Parlamentarnemu Rady Europy we wszystkich aspektach polityki lokalnej i regionalnej.

Zgodnie $\mathrm{z}$ art. 2 ust. 1 statutu CLRAE do pozostałych kompetencji Kongresu należą m.in.: podejmowanie działań w celu zapewnienia udziału społeczności lokalnych i regionalnych w realizacji idei zjednoczonej Europy, przedkładanie Komitetowi Ministrów RE propozycji promujących samorządność lokalną i regionalną, promowanie zagranicznej współpracy społeczności lokalnych i regionalnych, ścisła współpraca z Komitetem Regionów Unii Europejskiej w celu zapewnienia komplementarności ich działań. ${ }^{54}$ Ponadto do zadań Kongresu należy m.in.: analiza i sporządzanie raportów na temat stanu demokracji lokalnej i regionalnej w państwach członkowskich i państwach kandydujących, ze szczególnym uwzględnieniem przestrzegania postanowień Europejskiej Karty Samorządu Lokalnego oraz monitorowanie wyborów samorządowych (lokalnych lub regionalnych).

\section{Osiągnięcia CLRAE w zakresie legislacyjnym}

Kongres Władz Lokalnych i Regionalnych Rady Europy ma swój istotny udział w pracach legislacyjnych Rady Europy w zakresie samorządu terytorialnego i współpracy regionalnej.

Bez wątpienia fundamentalnym dokumentem z punktu widzenia ochrony praw społeczności lokalnych jest Europejska Karta Samorządu Lokalnego (European Charter of Local Self-government) przyjęta w Strasburgu 15 października 1985 roku przez Stałą Konferencję Władz Lokalnych i Regionalnych Europy. Polska ratyfikowała kartę 22 listopada 1993 roku. ${ }^{55}$

Karta jest prawnym instrumentem pozwalającym bronić autonomii i niezależności lokalnych społeczności i ustanawia wspólne europejskie standardy ochrony praw władz lokalnych. Definiuje ona pojęcie samorządu lokalnego jako „prawo i rzeczywistą zdolność wspólnot lokalnych do regulowania i zarządzania, w ramach prawa, na ich własną odpowiedzialność i na rzecz ich ludności, istotną częścią

53 Zob. I. Pietrzak, Polityka regionalna Unii Europejskiej i regiony w państwach członkowskich, Warszawa 2006, s. 275-276.

54 Statutory Resolution CM/Res (2011)2, adopted by the Committee of Ministers (19.01.2011); tryb dostępu: https:// wcd.coe.int, dnia 11.12.2012 r.

55 Dz.U. z 1994 r. Nr 124, poz. 607. W polskim systemie prawnym dokument ten występował w latach 1994-2006 pod nazwą „Europejska Karta Samorządu Terytorialnego”, jednak zgodnie z obwieszczeniem Ministra Spraw Zagranicznych z dnia 22 sierpnia 2006 o sprostowaniu błędu zamieniono jej tłumaczenie na „Europejska Karta Samorządu Lokalnego”. Zob. Obwieszczenie Ministra Spraw Zagranicznych z dnia 22 sierpnia 2006 o sprostowaniu błędu (Dz.U. z 2006 r. Nr 157, poz. 1107). 
spraw publicznych". ${ }^{56}$ Podkreśla również, że zasada samorządu lokalnego powinna być uznana przez prawo krajowe i, o ile to możliwe, przez Konstytucję. Ponadto Karta reguluje m.in.: ochronę prawną wspólnot lokalnych, kwestię finansowania samorządów, ochronę granic terytorialnych wspólnot lokalnych, status osób wybranych na szczeblu lokalnym, prawo samorządów do zrzeszania się.

Kongres Władz Lokalnych i Regionalnych ma również swój znaczący udział w pracach nad innymi konwencjami, kartami, konwencjami ramowymi Rady Europy. ${ }^{57}$ Do najważniejszych z nich należy zaliczyć:

- Europejską Konwencję Ramową o współpracy transgranicznej między wspólnotami i władzami terytorialnymi, sporządzoną w Madrycie dnia 21 maja 1980 roku $^{58}$ (Polska ratyfikowała konwencję w 1993 roku). Konwencja m.in. wprowadziła pojęcie współpracy transgranicznej do języka prawnego oraz zobowiązywała państwa sygnatariuszy do ułatwiania i wspierania współpracy transgranicznej wspólnot i władz terytorialnych,

- Konwencję o uczestnictwie obcokrajowców w życiu publicznym na szczeblu lokalnym, sporządzoną w Strasburgu 5 lutego 1992 roku, ${ }^{59}$ zgodnie z którą m.in. każda ze stron sygnatariuszy będzie starała się zapewnić cudzoziemcom zamieszkałym na jej terytorium prawo do udziału w głosowaniu oraz prawo do kandydowania w wyborach do władz lokalnych, jeśli spełniają oni te same prawne wymagania, które stosują się do obywateli tego państwa, a ponadto, byli legalnymi i stałymi mieszkańcami tego państwa przez 5 lat poprzedzających wybory,

- Europejską Konwencję Krajobrazową, sporządzoną we Florencji 20 października 2000 r., ${ }^{60}$ której celem jest promowanie ochrony, gospodarki i planowania krajobrazu, a także organizowanie współpracy europejskiej w zakresie zagadnień dotyczących krajobrazu. Konwencja nakłada na sygnatariuszy obowiązek zintegrowania krajobrazu z własną polityką w zakresie planowania regionalnego i urbanistycznego oraz własną polityką kulturalną, środowiskową, rolną, społeczną i gospodarczą,

- Europejską kartę języków regionalnych lub mniejszościowych, przyjętą w Strasburgu 5 listopada 1992 roku. ${ }^{61}$ Jej głównym zadaniem jest ochrona i zachowanie języków regionalnych i mniejszości narodowych. Zgodnie $\mathrm{z}$ jej postanowieniami sygnatariusze zobowiązują się m.in. opierać swoją

Art. 3 ust. 1 Europejska Karta Samorządu Lokalnego sporządzona w Strasburgu dnia 15 października 1985 r. (Dz.U. z 1994 r. Nr 124, poz. 607).

Na temat charakterystyki i klasyfikacji traktatów Rady Europy zob. F. Benoit-Rohmer, H. Klebes, Prawo Rady Europy. W stronę ogólnoeuropejskiej przestrzeni prawnej, Warszawa 2006, s. 93-117.

Dz.U. z 1993 r. Nr 61, poz. 287.

Zob. Rada Europy, Wybór konwencji Rady Europy, Warszawa 1999, s. 199-208.

Dz.U. z 2006 r. Nr 14, poz. 98.

Zob. Wybór konwencji Rady Europy, Warszawa 1999, s. 151-160. 
politykę, ustawodawstwo i praktykę działania na uznaniu języków regionalnych lub mniejszościowych za przejaw bogactwa kulturalnego, ułatwianiu posługiwania się tymi językami w życiu publicznym, prywatnym, kulturalnym, gospodarczym i społecznym,

- Europejską kartę o uczestnictwie młodych ludzi w życiu lokalnym i regionalnym przyjętą w 1992 i znowelizowaną w Strasburgu 23 maja 2003 roku. ${ }^{62}$ Karta zawiera wytyczne dla gmin, miast i regionów w zakresie promowania aktywnej polityki wobec młodych ludzi m.in.: w kwestii sportu i spędzania wolnego czasu, zatrudniania i walki z bezrobociem młodych, warunków mieszkaniowych i transportu, zdrowia, kultury, walki z przemocą, przestępczością i dyskryminacją.

\section{Formy aktywności CLRAE}

Działalność Kongresu Władz Lokalnych i Regionalnych Rady Europy jest bardzo szeroka i wielopłaszczyznowa.

Jedno z głównych założeń Rady Europy - promowanie demokracji i praw człowieka na kontynencie europejskim - jest realizowane przez Kongres Władz Lokalnych i Regionalnych poprzez misje monitorujące. Przedstawiciele CLRAE odbywają regularne wizyty kontrolne we wszystkich państwach członkowskich Rady Europy, monitorując przestrzeganie zasad zawartych w Europejskiej Karcie Samorządu Lokalnego. Po każdej tego typu wizytacji sporządzany jest szczegółowy raport z oceną realizacji postanowień Karty. Znajdują się w nim również wnioski i zalecenia pokontrolne. Raport jest następnie omawiany na sesji plenarnej Kongresu w Strasburgu. Misje monitorujące odbywają się również w przypadku niepokojących zdarzeń, gdy zachodzą ku temu uzasadnione powody i sprawa wymaga wyjaśnienia. ${ }^{63}$ Od 1995 roku powstało ponad 50 raportów na temat przestrzegania Europejskiej Karty Samorządu Lokalnego w krajach członkowskich. Tylko w 2010 roku odbyto 15 misji monitorujących. ${ }^{64}$ Wizyta przedstawicieli CLRAE jest również zawsze okazją do dialogu z władzami krajowymi i samorządowymi na temat stanu demokracji lokalnej w danym państwie. Należy podkreślić, że raporty w znacznym stopniu przyczyniły się do reform legislacyjnych w wielu państwach członkowskich Rady Europy poprawiających status samorządu terytorialnego i zwiększających jego kompetencje.

62 Tryb dostępu: http://www.coe.int/t/dg4/youth/Source/Coe_youth/Participation/COE_charter_participation_po.pdf, dnia 11.12.2012 r.

63 Np. w 2008 r. odbyła się misja monitorująca w Turcji w sprawie zbadanie skargi w związku z zawieszeniem i odwołaniem 4 burmistrzów w południowo-wschodniej Anatolii. Zob. http://www.coe.int/t/congress/Activities/.

64 W 2010 roku odbyły się misje monitorujące w następujących państwach: Czarnogóra, Austria, Rosja, Estonia, Turcja, Belgia, Rumunia, Malta, Serbia, Mołdawia, Ukraina, Słowenia, Łotwa, Albania i Francja. Zob. http://www. coe.int/t/congress/Activities/. 
Kolejnym ważnym elementem działalności Kongresu są misje obserwacyjne na wybory samorządowe w państwach członkowskich Rady Europy. Delegacja CLRAE obserwuje cały proces wyborczy - począwszy od procedur rejestracji kandydatów i komitetów, przez kampanię wyborczą, etap głosowania, zliczania głosów i ogłaszania wyników wyborów. Jednocześnie odbywają się spotkania z przedstawicielami władz państwowych, regionalnych i lokalnych, członkami komisji wyborczych, partii politycznych i komitetów wyborczych, organizacji pozarządowych oraz mediów. Po każdej misji obserwacyjnej sporządzany jest raport (omawiany następnie na sesji plenarnej). Zawiera on ocenę wyborów ze szczególnym uwzględnieniem kontekstu politycznego i społecznego, a także warunki prawne i organizację głosowania. Niektóre misje obserwacyjne są przeprowadzane wspólnie z przedstawicielami Zgromadzenia Parlamentarnego Rady Europy i Komisji Weneckiej.

W celu wzmocnienia demokracji lokalnej i współpracy transgranicznej Kongres Władz Lokalnych i Regionalnych Rady Europy aktywnie współpracuje z wieloma krajowymi i międzynarodowymi organizacjami samorządowymi. Uczestniczy również w projektach, których celem jest umożliwienie obywatelom większego udziału w lokalnej i regionalnej demokracji. Kongres Władz Lokalnych i Regionalnych Rady Europy powołał Local Democracy Agencies (LDA), aby ułatwić wspólnotom lokalnym zniszczonym przez wojnę w byłej Jugosławii korzystanie z pomocy na zasadzie umów partnerskich z miastami w Europie Zachodniej. Ponadto CLARE blisko współpracuje m.in. z European Network of Local and Regional Authority Training Establishments (ENTO), National Association of Local Authorities of Georgia (NALAG) i Network of Associations of Local Authorities of South-East Europe (NALAS).

Należy podkreślić też dobrą współpracę Kongresu Władz Lokalnych i Regionalnych Rady Europy z Komitetem Regionów Unii Europejskiej. Grupa kontaktowa CLRAE i Komitetu Regionów składa się z sześciu przedstawicieli z każdej z instytucji i zbiera się dwa razy w roku. Grupa ustala wspólny harmonogram prac, który następnie jest realizowany przez odpowiednie organy Kongresu Władz Lokalnych i Regionalnych Rady Europy i Komitet Regionów Unii Europejskiej.

\section{Podsumowanie}

Kongres Władz Lokalnych i Regionalnych Rady Europy pomimo faktu, że jest jedynie organem doradczym, odgrywa istotną rolę w rozwoju demokracji lokalnej i międzynarodowej współpracy samorządowej. Zgadzam się z tezą Ireny Pietrzyk, że obecnie „pomimo ograniczonych możliwości normatywnych Rady Europy (która opracowuje jedynie konwencje międzynarodowe wymagające ratyfikacji przez kraje członkowskie) CLRAE wydaje się mieć większe możliwości od- 
działywania na sytuację samorządów europejskich niż Komitet Regionów (...)". ${ }^{65}$ Wkład CLRAE w przygotowanie Europejskiej Karty Samorządu Lokalnego (wyprowadzającej wspólne europejskie standardy ochrony praw władz lokalnych) jest najlepszym tego przykładem. Ponadto regularne misje monitorujące przestrzegania Karty i permanentny dialog z rządami państw członkowskich Rady Europy w sprawach samorządu terytorialnego dodatkowo wzmacniają pozycje władz lokalnych i regionalnych w Europie. Należy również podkreślić znaczenie misji obserwacyjnych CLRAE w trakcie wyborów samorządowych. Kongres Władz Lokalnych i Regionalnych Rady Europy jest także forum, na którym przedstawiciele samorządów terytorialnych z całej Europy (gmin, miast, regionów) mogą dzielić się swoimi doświadczeniami oraz pozytywnie oddziaływać na rozwój demokracji lokalnej. 


\section{THE ROLE OF THE CONGRESS OF LOCAL AND REGIONAL AUTHORITIES OF THE COUNCIL OF EUROPE (CLRAE) IN INTERNATIONAL COOPERATION IN LOCAL AUTHORITIES}

The article presents the institutions of Congress of Local and Regional Authorities of the Council of Europe. Its role is to promote local and regional democracy, improve local and regional governance and strengthen authorities' self-government. CLRAE is a pan-European political assembly, the 636 members of which hold elective office representing over 200,000 authorities in 47 European states.

Keywords:

Congress of Local and Regional Authorities; CLRAE; European Charter of Local Self-Government; local and regional democracy, Council of Europe 